\title{
Does Aquaporin-1 expression have clinical significance in serous epithelial ovarian cancer?
} Aquaporin-1 ekspresyonunun seröz epitelyal over kanserinde klinik önemi var mıdır?

\author{
Mustafa Kemal Takal', Cem Baykal', Eralp Başer', Mustafa Derda Kaya'1, Polat Dursun', Özlem Özen², \\ Asuman Nihan Haberal', Ali Ayhan ${ }^{1}$ \\ 'Department of Obstetrics and Gynecology, Division of Gynecological Oncology, \\ Başkent University School of Medicine, Ankara, Turkey \\ ${ }^{2}$ Department of Pathology, Başkent University School of Medicine, Ankara, Turkey
}

\section{Abstract}

Objective: To assess the relationship between Aquaporin-1 (AQP1) expression and clinicopathological variables in serous epithelial ovarian cancer (EOC).

Material and Methods: Serous EOC cases treated in our institution between January 2007 and December 2009 were included in the study. A semi-quantitative immunohistochemical method was used to determine AQP1 expression levels, intratumoral microvessel density (IMD) and AQP1/IMD ratios. The relationship between these parameters and clinicopathological variables were assessed. $P$ values less than 0.05 was considered statistically significant.

Results: A total of 55 cases of serous EOC were included in the study. AQP1 was strongly expressed in the membranes of microvessels and small vessels within all tumor tissues. In a few cases, AQP1 expression was also observed in the membrane of interstitial cells and in individual tumor cells. A positive correlation was detected between preoperative CA125 levels and the expression of AQP1 (R: 0.277, p<0.05). AQP1 expression was similar between FIGO stage I-II and FIGO stage III-IV cases ( $p>0.05$ ). A significant relationship did not exist between AQP1 expression and FIGO stage, lymph node metastasis or ascites volume $(\mathrm{p}>0.05)$

Conclusion: In this study, AQP1 expression did not have a significant association with important clinicopathological variables in serous EOC. Future studies are needed to determine AQP1 expression in other histological types of EOC.

(J Turkish-German Gynecol Assoc 2013; 14: 130-5)

Key words: Aquaporin-1, intratumoral microvessel density, serous epithelial ovarian cancer

Received: 15 April, 2013

Accepted: 16 May, 2013
Özet

Amaç: Seröz epitelyal over kanserlerinde (EOK) Aquaporin-1 (AQP1) ekspresyonunun klinik ve patolojik değişkenlerle ilişkisini araştırmaktır. Gereç ve Yöntemler: Kurumumuzda Ocak 2007 ile Aralık 2009 tarihleri arasında tedavi edilen seröz EOK olguları çalışmaya dahil edildi. AQP1 ekspresyonları ile intratümöral mikrodamar dansitesi (IMD) ve AQP1/IMD oranlarının belirlenmesinde semikantitatif immünhistokimyasal bir metod kullanıldı. Bu parametreler ile klinik ve patolojik değişkenlerin ilişkisi incelendi. $P$ değeri 0.05 'den küçük olduğunda istatistiksel olarak anlamlı kabul edildi.

Bulgular: Çalışmaya toplam 55 seröz EOK olgusu dahil edildi. Tüm olgularda, tümör dokusu içindeki mikrodamarlar ve küçük damarların membranlarında güçlü AQP1 ekspresyonu saptandı. Birkaç olguda, interstisyel hücre membranları ve tümör hücrelerinin içinde de AQP1 ekspresyonu gözlendi. Preoperatif CA125 düzeyleri ve AQP1 ekspresyonu arasında pozitif korelasyon saptandı (R: 0.277, $\mathrm{p}<0.05$ ). FIGO evre I-II ve evre III-IV olgular arasındaki AQP1 ekspresyonu benzerdi ( $p>0.05)$. AQP1 ekspresyonu ile FIGO evresi, lenf nodu metastazı ve asit volümü arasında anlamlı bir ilişki saptanmadı ( $\mathrm{p}>0.05)$.

Sonuç: Çalışmamızda seröz EOK'de AQP1 ekspresyonu ile önemli klinik ve patolojik değişkenler arasında anlamlı bir ilişki saptanmamıştır. EOK'nin diğer histolojik tiplerindeki AQP1 ekspresyonunun belirlenebilmesi için gelecek çalışmalara ihtiyaç vardır.

(J Turkish-German Gynecol Assoc 2013; 14: 130-5)

Anahtar kelimeler: Aquaporin-1, intratümöral mikrodamar dansitesi, seröz epitelyal over kanseri

Geliş Tarihi: 15 Nisan 2013

Kabul Tarihi: 16 Mayıs 2013

\section{Introduction}

Epithelial ovarian cancer (EOC) is the most lethal gynecologic cancer, with a five-year overall survival of approximately 31 to $53 \%$, considering all stages (1-3). Generally accepted clinicopathological variables that may have an impact on survival are tumor histology, disease stage, patient age, performance status of the patient, presence of ascites, residual tumor burden after surgery and preoperative CA-125 level (4-16).
Aquaporins are a group of homologous water channel proteins, which are expressed in various tissues (17-19). Aquaporin-1 (AQP1) has important functions in various organs such as the kidney, central and peripheral nervous system, eye, lacrimal glands, salivary glands, lungs, pleura, gastrointestinal system, female and male reproductive system, inner ear and skin.

Considering its function in angiogenesis, the possible role of AQP1 in carcinogenesis, tumor progression and metastasis ability has been an area of interest $(20,21)$. Its distribution 
and expression intensity on various cells may have an effect on transvascular fluid flow and tumor cell fluid transport in EOC. A previous study has demonstrated that there is a strong positive correlation between AQP1 expression and intratumoral microvessel density (IMD) in EOC (22). In the present study, we evaluated AQP1 expression in serous EOC, in order to determine its association with clinical and pathological variables of prognostic significance.

\section{Materials and Methods}

The study was performed at the gynecologic oncology department of Başkent University School of Medicine, Ankara, Turkey, following scientific and ethical approval from the institutional review board. Tumor specimens were collected from 55 cases diagnosed with primary serous EOC between January 2007 and December 2009. All of the cases had undergone primary debulking surgery without previous neoadjuvant chemotherapy. All of the patients underwent primary debulking surgery, and optimal cytoreduction was possible in 39 (70.9\%) cases. Data including patient age, disease stage, tumor grade, preoperative CA-125 level, ascites volume, ascites cytology, lymph node metastasis, lymphovascular space invasion and Gynecologic Oncology Group (GOG)/Eastern Cooperative Oncology Group (ECOG) performance status were recorded for each case (23). All of the study specimens were selected from primary tumor tissues within the ovary. Following initial examination of hematoxylin and eosin stained slides, the most appropriate sections were selected for immunohistochemical analysis. AQP1 expression and IMD (CD34 counts) were determined using a semi-quantitative immunohistochemical method.

Formalin-fixed, paraffin-embedded $4 \mu \mathrm{m}$-thick tissue sections were de-paraffinized with xylene and rehydrated with graded alcohols. Endogenous peroxidase was blocked with 10\% hydrogen peroxidase and antigen retrieval reaction was carried out by boiling in $10 \mathrm{mM}$ sodium citrate ( $\mathrm{pH} \mathrm{6.0)}$ buffer for 90 seconds. Normal non-immune serum was applied to reduce non-specific binding. Samples were then incubated with AQP1 primary antibody (1:500 dilution, clone: 1/A5F6 monoclonal $\mathrm{Ab}$, GeneTex Inc., CA,USA) and CD34 primary antibody (1:100 dilution, clone: Q Bend/10, mouse monoclonal Ab, ScyTek Laboratories, UT, USA) at room temperature for 60 minutes, and then with appropriate secondary antibodies (PicTure ${ }^{\mathrm{TM}}$ Kits, Zymed Laboratories, NY, USA) at room temperature for 30 minutes. Visualization of the reaction with diaminobenzidine was performed and the slides counterstained with hematoxylin. The negative control was carried out substituting phosphate buffered saline (PBS) for the primary antibody. Positive controls were prepared with AQP1 reactive kidney tissue.

IMD scores were assessed by immunostaining for CD34 as described by Weidner et al. (24). Immune-stained sections were initially assessed in low magnification ( $x 40)$. Within the tumor or adjacent tissue, areas with the highest number of highlighted microvessels, i.e. "hot spots" were identified. Subsequently, the IMD score was determined by counting all vessels at high magnification (x400). Determination of the staining reaction was strictly limited to the hot spot area. Every sin stained lumen was recorded as one countable microvessel. Single positive cells without a visible lumen were also were regarded as a single microvessel. Two independent pathologists performed the immunohistochemical analyses. The average value of the results from both pathologists was used for all subsequent calculations. If more than 30\% discordance was present between these two values, the slides were re-evaluated by both pathologists to calculate a final value. AQP1 expression scores within tumor microvessels were evaluated in the same manner. As the AQP1 expression had variance between cases and within the various hot spots, the AQP1/IMD ratio was used to represent the expression levels of AQP1, in an effort to prevent error caused by this variation.

Study data were analyzed using the Statistical Package for Social Sciences (SPSS) version 17.0 (SPSS Inc., Chicago, IL, USA). The associations were determined between clinical and prognostic variables (patient age, FIGO stage, tumor grade, ascites volume, ascites cytology, lymph node involvement status, GOG/ECOG performance status, lymphovascular space invasion (LVSI) status, preoperative CA 125 level) and AQP1 expression, IMD and the AQP1/IMD ratio. T-tests were used to compare values between two groups, and one-way analysis of variance (ANOVA, Kruskal-Wallis post hoc test) was performed when three or more groups were present. Correlations were determined by calculating the Pearson correlation coefficients. $P$ values less than 0.05 were considered statistically significant.

\section{Results}

A total of 55 serous epithelial ovarian cancer (EOC) cases were included in the study. The mean patient age was 56.6 \pm 10.8 (minimum 31, maximum 83). Fifty (90.9\%) cases had advanced stage (FIGO III-IV), whereas five (9.1\%) cases had early stage (FIGO stage I-II) disease. In the histopathological examination, $46(83.6 \%)$ cases had grade 3 , and $9(16.4 \%)$ cases had grade 2 tumors. The clinical and prognostic parameters of the study cases are presented in Table 1.

Aquaporin-1 (AQP1) protein was strongly expressed in the membrane of microvessels and small vessels in all primary serous EOCs (Figure 1). AQP1 expression was also observed in the membrane of interstitial cells in tumor tissue (Figure 2). In two cases, AQP1 was expressed in tumor cell membranes (Figure 3). AQP1 expression was not observed in the cytoplasm of tumor cells.

Mean AQP1 expression levels, intratumoral microvessel density (IMD) expression levels and AQP1/IMD ratios in relation with clinical and prognostic parameters are presented in Table 2.

There was a positive correlation between the preoperative CA 125 level and AQP1 expression (R: 0.277, $\mathrm{p}=0.03$ ). There was no statistically significant difference for AQP1 expression between the FIGO stage I-II and FIGO stage III-IV groups, nor between the grade 2 and grade 3 tumor groups $(p=0.24)$. There was also no correlation between AQP1 expression and IMD. A statistically significant difference was not present between cases grouped for ascites volume, ascites cytology, lymph node metastasis, lymphovascular space invasion (LVSI), preoperative CA 125 level or performance status for AQP1 expression, IMD expression and the AQP1/IMD ratio ( $\mathrm{p}>0.05$ ) (Table 2). 
Table 1. Clinical and prognostic parameters of the study cases

\begin{tabular}{|c|c|c|}
\hline Parameters & $\begin{array}{c}\text { Cases } \\
(\text { Total } n=55)\end{array}$ & $\begin{array}{l}\text { Percentage } \\
\text { (\%) }\end{array}$ \\
\hline \multicolumn{3}{|l|}{ FIGO stage } \\
\hline I-II & 5 & 9.1 \\
\hline III-IV & 50 & 90.9 \\
\hline \multicolumn{3}{|l|}{ Tumor grade } \\
\hline Grade 1 & 0 & 0 \\
\hline Grade 2 & 9 & 16.4 \\
\hline Grade 3 & 46 & 83.6 \\
\hline \multicolumn{3}{|c|}{ Preoperative CA 125 level (U/mL) } \\
\hline$<35$ & 1 & 1.8 \\
\hline $35-499$ & 22 & 40.0 \\
\hline$\geq 500$ & 32 & 58.2 \\
\hline \multicolumn{3}{|c|}{ Ascites volume (mL) } \\
\hline$<500$ & 17 & 30.9 \\
\hline $500-999$ & 10 & 18.2 \\
\hline$\geq 1000$ & 28 & 50.8 \\
\hline \multicolumn{3}{|c|}{ Ascites cytology } \\
\hline Negative & 24 & 43.6 \\
\hline Positive & 31 & 56.4 \\
\hline \multicolumn{3}{|c|}{ Lymph node metastasis } \\
\hline Absent & 18 & 32.7 \\
\hline Present & 37 & 67.3 \\
\hline \multicolumn{3}{|l|}{ LVSI $^{2}$} \\
\hline Absent & 23 & 41.8 \\
\hline Present & 32 & 58.2 \\
\hline \multicolumn{3}{|c|}{ GOG/ECOG ${ }^{3}$ performance status } \\
\hline 1 & 13 & 23.6 \\
\hline 2 & 10 & 18.2 \\
\hline 3 & 21 & 38.2 \\
\hline 4 & 11 & 20.0 \\
\hline \multicolumn{3}{|c|}{$\begin{array}{l}\text { FIGO: International Federation of Gynecology and Obstetrics; LVSI } \\
\text { Lymphovascular space invasion; GOG/ECOG: Gynecologic Oncology } \\
\text { Group/ Eastern Cooperative Oncology Group. } \\
\text { P values }<0.05 \text { were considered statistically significant }\end{array}$} \\
\hline
\end{tabular}

\section{Discussion}

Aquaporins were initially identified nearly 20 years ago (25). Most of these proteins are expressed in epithelial and endothelial cells, where they regulate trans-membranous fluid transport (17-19). AQP1 is most strongly expressed in the microvascular endothelium, in normal tissues such as the brain, cornea and intestinal lacteals (19). In a previous study, it was demonstrated that microvessel AQP1 expression in brain tumors was associated with increased water permeability of the blood brain barrier, which ultimately resulted in brain tumor edema in these cases $(26,27)$. In another study, increased expression of AQP1 was demonstrated in all stages of colon cancer (28).

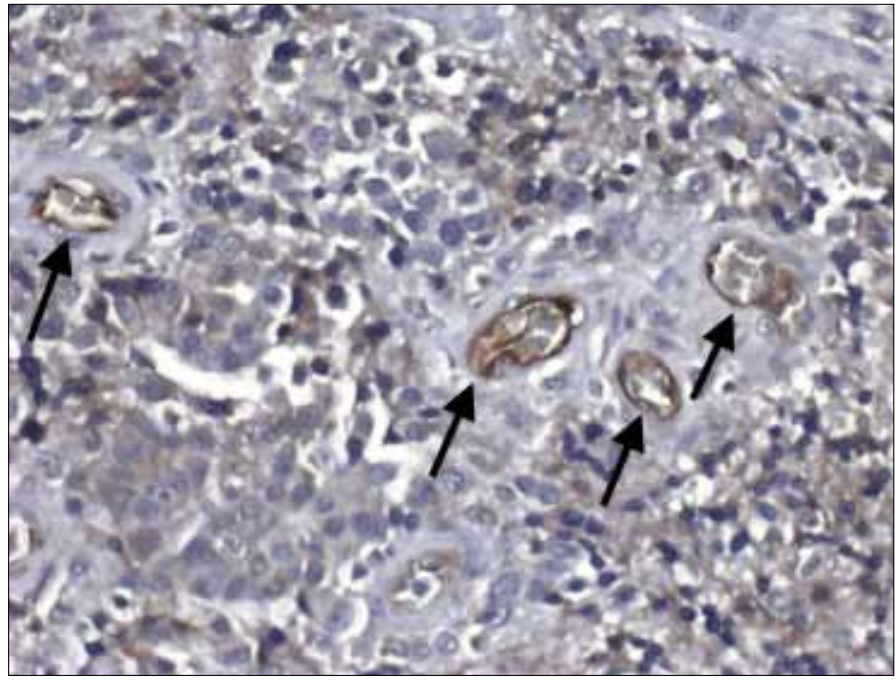

Figure 1. Strong Aquaporin-1 (AQP1) staining in membranes of microvessels within the tumor (black arrows; $X$ 400)

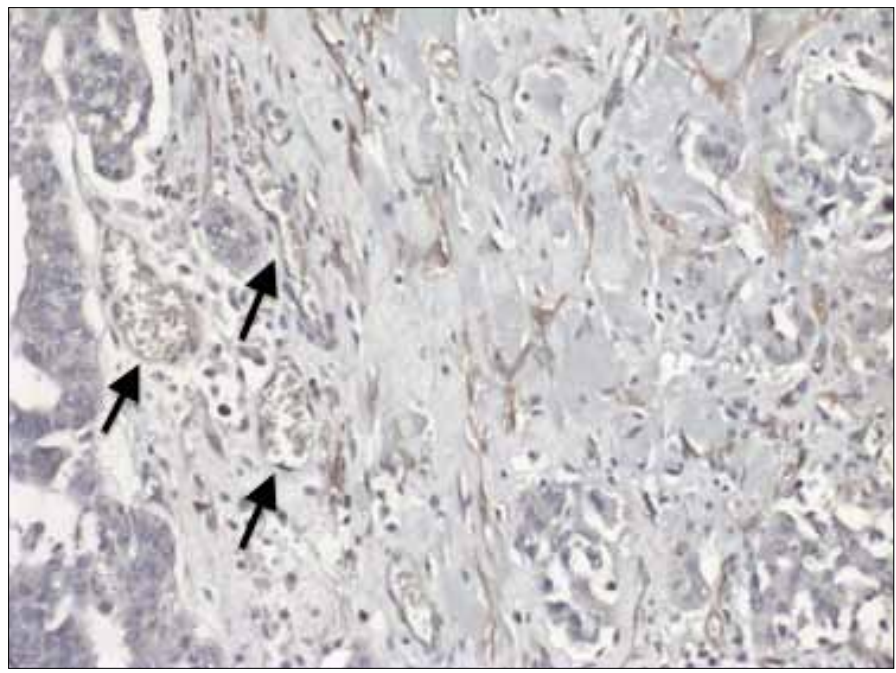

Figure 2. Aquaporin-1 (AQP1) staining in membranes of interstitial cells (black arrows; X400)

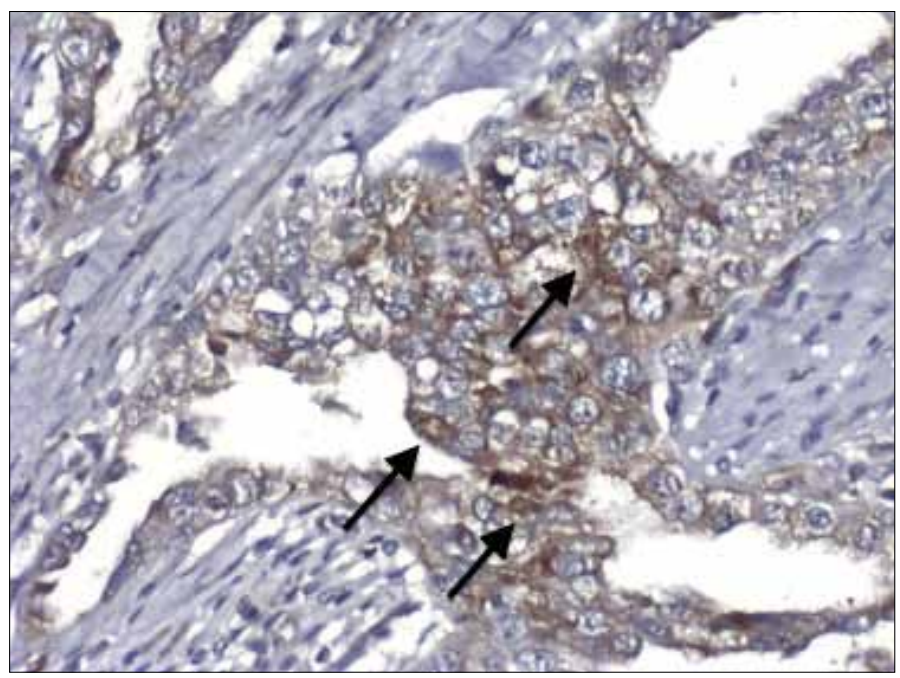

Figure 3. Aquaporin-1 (AQP1) staining in membranes of tumor cells (black arrows; X 400) 
Table 2. Aquaporin-1 (AQP1) expression, intratumoral microvessel density (IMD) and the AQP1/IMD ratio in primary serous epithelial ovarian cancer with relation to clinical and prognostic parameters

\begin{tabular}{|c|c|c|c|c|c|c|c|}
\hline & Cases (n) & AQP1 & $\mathbf{p}^{*}$ & IMD & $\mathbf{p}^{*}$ & AQP1/IMD & $\mathbf{p}^{*}$ \\
\hline \multicolumn{8}{|l|}{ FIGO stage } \\
\hline I-II & 5 & $31.8 \pm 27.4$ & \multirow[b]{2}{*}{$>0.05$} & $24.6 \pm 7.4$ & \multirow[b]{2}{*}{$>0.05$} & $1.58 \pm 1.87$ & \multirow[b]{2}{*}{$>0.05$} \\
\hline III-IV & 50 & $32.7 \pm 18.9$ & & $32.5 \pm 19.8$ & & $1.26 \pm 0.90$ & \\
\hline \multicolumn{8}{|l|}{ Tumor grade } \\
\hline Grade 2 & 9 & $41.7 \pm 34.0$ & \multirow[b]{2}{*}{$>0.05$} & $28.7 \pm 11.6$ & \multirow[b]{2}{*}{$>0.05$} & $1.76 \pm 1.66$ & \multirow[b]{2}{*}{$>0.05$} \\
\hline Grade 3 & 46 & $30.8 \pm 15.2$ & & $32.3 \pm 20.3$ & & $1.20 \pm 0.81$ & \\
\hline \multicolumn{8}{|c|}{ Lymph node metastasis } \\
\hline Absent & 18 & $29.8 \pm 18.1$ & \multirow[b]{2}{*}{$>0.05$} & $31.1 \pm 17.2$ & \multirow[b]{2}{*}{$>0.05$} & $1.31 \pm 1.30$ & \multirow[b]{2}{*}{$>0.05$} \\
\hline Present & 37 & $34.0 \pm 20.2$ & & $32.1 \pm 20.2$ & & $1.29 \pm 0.84$ & \\
\hline \multicolumn{8}{|l|}{ LVSI } \\
\hline Absent & 23 & $33.5 \pm 18.7$ & \multirow[b]{2}{*}{$>0.05$} & $27.6 \pm 14.7$ & \multirow[b]{2}{*}{$>0.05$} & $1.47 \pm 1.17$ & \multirow[b]{2}{*}{$>0.05$} \\
\hline Present & 32 & $32.0 \pm 20.4$ & & $34.7 \pm 21.6$ & & $1.17 \pm 0.86$ & \\
\hline \multicolumn{8}{|c|}{ Ascites volume $(\mathrm{mL})$} \\
\hline$<500$ & 17 & $28.2 \pm 16.1$ & \multirow[b]{3}{*}{$>0.05$} & $30.9 \pm 16.6$ & \multirow[b]{3}{*}{$>0.05$} & $1.15 \pm 1.07$ & \multirow[b]{3}{*}{$>0.05$} \\
\hline $500-999$ & 10 & $33.2 \pm 30.1$ & & $31.5 \pm 15.0$ & & $1.30 \pm 1.14$ & \\
\hline$\geq 1000$ & 28 & $35.1 \pm 16.9$ & & $32.3 \pm 22.2$ & & $1.38 \pm 0.94$ & \\
\hline \multicolumn{8}{|c|}{ Ascites cytology } \\
\hline Negative & 24 & $32.2 \pm 24.3$ & \multirow[b]{2}{*}{$>0.05$} & $35.8 \pm 26.6$ & \multirow[b]{2}{*}{$>0.05$} & $1.24 \pm 1.21$ & \multirow[b]{2}{*}{$>0.05$} \\
\hline Positive & 31 & $31.7 \pm 13.9$ & & $28.6 \pm 10.0$ & & $1.30 \pm 0.82$ & \\
\hline \multicolumn{8}{|c|}{ Preoperative CA 125 level (U/mL) } \\
\hline$<35$ & 1 & 22 & \multirow[b]{3}{*}{$>0.05$} & 35 & \multirow[b]{3}{*}{$>0.05$} & 0.62 & \multirow[b]{3}{*}{$>0.05$} \\
\hline $35-499$ & 22 & $30.8 \pm 15.1$ & & $30.1 \pm 16.5$ & & $1.30 \pm 0.98$ & \\
\hline$\geq 500$ & 32 & $34.2 \pm 22.4$ & & $32.7 \pm 21.2$ & & $1.31 \pm 1.04$ & \\
\hline \multicolumn{8}{|c|}{ GOG/ECOG performance status } \\
\hline 1 & 13 & $37.6 \pm 31.7$ & \multirow[b]{4}{*}{$>0.05$} & $31.0 \pm 15.1$ & \multirow[b]{4}{*}{$>0.05$} & $1.53 \pm 1.50$ & \\
\hline 2 & 10 & $34.3 \pm 15.5$ & & $36.5 \pm 19.4$ & & $1.16 \pm 0.74$ & \\
\hline 3 & 21 & $30.4 \pm 13.4$ & & $31.0 \pm 24.8$ & & $1.26 \pm 0.67$ & \\
\hline 4 & 11 & $29.5 \pm 14.8$ & & $29.9 \pm 10.4$ & & $1.20 \pm 1.11$ & $>0.05$ \\
\hline
\end{tabular}

Previous studies have demonstrated that AQP1 protein is strongly expressed in small vessels, but not in the cytoplasm, in nearly all EOC types $(22,29)$. AQP1 was localized in the microvessel epithelium in these cases. Additionally, the expression of AQP1 was demonstrated on the membranes of interstitial cells of ovarian cancer tissue, and rarely on tumor cell membranes $(22,29)$. In our study, strong AQP1 protein expression was found in all primary serous EOC microvessels and small vessels. AQP1 expression was also demonstrated in interstitial cell membranes and tumor cells in a few cases. AQP1 was not expressed in the tumor cell cytoplasm. These findings are consistent with previous reports and support the theory that AQP1 has a role in transvascular water flow and fluid transport of tumor cells in EOC patients (22, 29). Our findings also suggest that malignant ovarian tumors have increased vascular permeability, like other tumor types (30).
The number of microvessels may be different within different tumors and different vascular areas that are evaluated. This may lead to incorrect $\mathrm{AQP1}$ expression results. Therefore, the $A Q P 1 / I M D$ ratio may reflect $A Q P 1$ expression better in EOC specimens, as IMD reflects the microvessel count within the tumor (22). In our study, IMD was determined by CD34 staining. In previous studies, anti-CD34 antibodies were reported to be superior to anti-CD31 and factor VIII related antigen to identify poorly differentiated endothelial cells $(31,32)$. The growth and metastasis of a tumor depends mostly on neovascularization $(24,33,34)$. IMD was reported to be higher in malignant ovarian tumors with respect to borderline tumors and also higher in borderline tumors with respect to benign tumors $(35,36)$. AQP1 expression and IMD together with AQP1/IMD ratio had no significant relationship with FIGO stage, lymph node 
metastasis, ascites volume and tumor grade in this study. In addition, relationships with other clinicopathological parameters such as age, performance status and preoperative CA125 levels were not detected. There was also no correlation between AQP1 expression and IMD. These findings were in contrast with a previous study in which AQP1 expression in microvessels of EOC had a significant association with ascites volume, FIGO stage and lymph node metastases. However, no relationship was reported between AQP1 expression and histological type or tumor grade (22). In our study, a positive correlation was found between AQP1 expression and the preoperative CA 125 level. The possible mechanisms underlying this finding should be further assessed in future trials.

In summary, AQP1 expression levels did not have a significant relationship between FIGO stage, ascites volume and lymph node metastasis in our study. According to these findings, the expression of AQP1 in serous EOC does not appear to contribute to the formation of ascites or impact on the prognosis of the disease. Future studies with larger sample sizes and other histological types are needed to clarify the clinical importance of AQP1 expression in EOC.

Ethics Committee Approval: Ethical and scientific approval was obtained from Başkent University Medical School institutional review board.

Informed Consent: Informed consent was obtained from the participants of this study participants.

Peer-review: Externally peer-reviewed.

Author contributions: Concept-M.K.T., C.B.;Design-M.K.T., C.B., A.A., O.O., A.N.H.; Supervision A.A.; Resource-A.A.; Materials A.A., P.D., O.O., A.N.H.; Data Collection\&/or Processing - M.K.T., M.D.K., E.B.; Analysis\&/or Interpretation - M.K.T., E.B.; Literature Search - M.K.T.; Writing - M.K.T., E.B.; Critical Reviews - A.A., C.B., P.D.

Conflict of Interest: The authors declare that there are no conflicts of interest.

Financial Disclosure: The study was financially supported by Başkent University Medical School.

\section{References}

1. Siegel R, Naishadham D, Jemal A. Cancer statistics, 2012. CA: a cancer journal for clinicians. 2012; 62: 10-29. [CrossRef]

2. Jemal A, Siegel R, Ward E, Hao Y, Xu J, Thun MJ. Cancer statistics, 2009. CA Cancer J Clin. 2009; 59: 225-49. [CrossRef]

3. Heintz AP, Odicino F, Maisonneuve P, Quinn MA, Benedet JL, Creasman WT, et al. Carcinoma of the ovary. FIGO 6th Annual Report on the Results of Treatment in Gynecological Cancer. Int $\mathrm{J}$ Gynaecol Obstet 2006; 95 Suppl 1: S161-92. [CrossRef]

4. Hoskins WJ, Bundy BN, Thigpen JT, Omura GA. The influence of cytoreductive surgery on recurrence-free interval and survival in small-volume stage III epithelial ovarian cancer: a Gynecologic Oncology Group study. Gynecol Oncol 1992; 47: 159-66. [CrossRef]

5. Hoskins WJ, McGuire WP, Brady MF, Homesley HD, Creasman WT, Berman M, et al. The effect of diameter of largest residual disease on survival after primary cytoreductive surgery in patients with suboptimal residual epithelial ovarian carcinoma. Am J Obstet Gynecol 1994; 170: 974-9. [CrossRef]
6. Lund B, Williamson P, van Houwelingen HC, Neijt JP. Comparison of the predictive power of different prognostic indices for overall survival in patients with advanced ovarian carcinoma. Cancer Res 1990; 50: 4626-9.

7. Marsoni S, Torri V, Valsecchi MG, Belloni C, Bianchi U, Bolis G, et al. Prognostic factors in advanced epithelial ovarian cancer. (Gruppo Interregionale Cooperativo di Oncologia Ginecologica (GICOG)). Br J Cancer 1990; 62: 444-50. [CrossRef]

8. Neijt JP, ten Bokkel Huinink WW, van der Burg ME, van Oosterom AT, Willemse PH, Vermorken JB, et al. Long-term survival in ovarian cancer. Mature data from The Netherlands Joint Study Group for Ovarian Cancer. Eur J Cancer 1991; 27: 1367-72. [CrossRef]

9. Omura GA, Brady MF, Homesley HD, Yordan E, Major FJ, Buchsbaum $\mathrm{HJ}$, et al. Long-term follow-up and prognostic factor analysis in advanced ovarian carcinoma: the Gynecologic Oncology Group experience. J Clin Oncol 1991; 9: 1138-50.

10. Schildkraut JM, Halabi S, Bastos E, Marchbanks PA, McDonald JA, Berchuck A. Prognostic factors in early-onset epithelial ovarian cancer: a population-based study. Obstet Gynecol 2000; 95: 119-27. [CrossRef]

11. Puls LE, Duniho T, Hunter JE, Kryscio R, Blackhurst D, Gallion H. The prognostic implication of ascites in advanced-stage ovarian cancer. Gynecol Oncol 1996; 61: 109-12. [CrossRef]

12. van Houwelingen JC, ten Bokkel Huinink WW, van der Burg ME, van Oosterom AT, Neijt JP. Predictability of the survival of patients with advanced ovarian cancer. J Clin Oncol 1989; 7: 769-73.

13. Geisler JP, Miller GA, Lee TH, Harwood RM, Wiemann MC, Geisler HE. Relationship of preoperative serum CA-125 to survival in epithelial ovarian carcinoma. J Reprod Med 1996; 41: 140-2.

14. Parker D, Bradley C, Bogle SM, Lay J, Masood M, Hancock AK, et al. Serum albumin and CA125 are powerful predictors of survival in epithelial ovarian cancer. Br J Obstet Gynaecol 1994; 101: 888-93. [CrossRef]

15. Schneider D, Halperin R, Halperin D, Bukovsky I, Hadas E. Prediction of the survival of patients with advanced ovarian cancer according to a risk model based on a scoring system. Eur J Gynaecol Oncol 1998; 19: 547-52.

16. Warwick J, Kehoe S, Earl H, Luesley D, Redman C, Chan KK. Long-term follow-up of patients with advanced ovarian cancer treated in randomised clinical trials. Br J Cancer 1995; 72: 1513-7. [CrossRef]

17. Borgnia M, Nielsen S, Engel A, Agre P. Cellular and molecular biology of the aquaporin water channels. Annu Rev Biochem 1999; 68: 425-58. [CrossRef]

18. Verkman AS, Mitra AK. Structure and function of aquaporin water channels. Am J Physiol Renal Physiol 2000; 278: F13-28.

19. Verkman AS. Aquaporin water channels and endothelial cell function. J Anat 2002; 200: 617-27. [CrossRef]

20. Benga G. Water channel proteins (later called aquaporins) and relatives: past, present, and future. IUBMB life 2009; 61: 112-33. [CrossRef]

21. Zhang W, Zitron E, Homme M, Kihm L, Morath C, Scherer D, et al. Aquaporin-1 channel function is positively regulated by protein kinase C. J Biol Chem 2007; 282: 20933-40. [CrossRef]

22. Yang JH, Shi YF, Chen XD, Qi WJ. The influence of aquaporin-1 and microvessel density on ovarian carcinogenesis and ascites formation. Int J Gynecol Cancer 2006; 16 Suppl 1: 400-5. [CrossRef]

23. Oken MM, Creech RH, Tormey DC, Horton J, Davis TE, McFadden ET, et al. Toxicity and response criteria of the Eastern Cooperative Oncology Group. Am J Clin Oncol 1982; 5: 649-55. [CrossRef]

24. Weidner N. Current pathologic methods for measuring intratumoral microvessel density within breast carcinoma and other solid tumors. Breast Cancer Res Treat 1995; 36: 169-80. [CrossRef] 
25. Denker BM, Smith BL, Kuhajda FP, Agre P. Identification, purification, and partial characterization of a novel Mr 28,000 integral membrane protein from erythrocytes and renal tubules. J Biol Chem 1988; 263: 15634-42.

26. Papadopoulos MC, Saadoun S, Davies DC, Bell BA. Emerging molecular mechanisms of brain tumour oedema. Br J Neurosurg 2001; 15: 101-8. [CrossRef]

27. Saadoun S, Papadopoulos MC, Davies DC, Bell BA, Krishna S. Increased aquaporin 1 water channel expression in human brain tumours. Br J Cancer 2002; 87: 621-3. [CrossRef]

28. Moon C, Soria JC, Jang SJ, Lee J, Obaidul Hoque M, Sibony M, et al. Involvement of aquaporins in colorectal carcinogenesis. Oncogene 2003; 22: 6699-703. [CrossRef]

29. Brustmann H, Riss P, Naude S. The relevance of angiogenesis in benign and malignant epithelial tumors of the ovary: a quantitative histologic study. Gynecol Oncol 1997; 67: 20-6. [CrossRef]

30. Yuan F, Leunig M, Huang SK, Berk DA, Papahadjopoulos D, Jain RK. Microvascular permeability and interstitial penetration of sterically stabilized (stealth) liposomes in a human tumor xenograft. Cancer Res 1994; 54: 3352-6.
31. Tanigawa N, Amaya H, Matsumura M, Lu C, Kitaoka A, Matsuyama $\mathrm{K}$, et al. Tumor angiogenesis and mode of metastasis in patients with colorectal cancer. Cancer Res 1997; 57: 1043-6.

32. Vieira SC, Zeferino LC, Da Silva BB, Aparecida Pinto G, Vassallo J, Carasan GA, et al. Quantification of angiogenesis in cervical cancer: a comparison among three endothelial cell markers. Gynecol Oncol 2004; 93: 121-4. [CrossRef]

33. Liotta LA, Stetler-Stevenson WG. Tumor invasion and metastasis: an imbalance of positive and negative regulation. Cancer Res 1991; 51(18 Suppl): 5054s-9s.

34. Folkman J, Watson K, Ingber D, Hanahan D. Induction of angiogenesis during the transition from hyperplasia to neoplasia. Nature 1989; 339: 58-61. [CrossRef]

35. Abulafia O, Ruiz JE, Holcomb K, Dimaio TM, Lee YC, Sherer DM. Angiogenesis in early-invasive and low-malignant-potential epithelial ovarian carcinoma. Obstet Gynecol 2000; 95: 548-52. [CrossRef]

36. Schoell WM, Pieber D, Reich O, Lahousen M, Janicek M, Guecer $\mathrm{F}$, et al. Tumor angiogenesis as a prognostic factor in ovarian carcinoma: quantification of endothelial immunoreactivity by image analysis. Cancer 1997; 80: 2257-62. [CrossRef] 